\title{
The Road to Disruptive Success
}

\author{
Alberto Abadia \\ Department of Business Administration \\ Universitat Politècnica de Catalunya (UPC) \\ Barcelona, Spain
}

\begin{abstract}
This article explains the study conducted in order to test the hypothesis that the combination of disruptive innovation or, at least, revolutionary innovation, and visionary leadership are necessary conditions for the disruptive success of innovationrelated startups. The author ranked, short-listed and then analyzed five cases in North America, one in Europe and three in East Asia. The analysis validates the tested hypothesis, suggests additional hypotheses and tips for further research.
\end{abstract}

Keywords - startups; innovation; tecnology; management; disruptive innovation; revolutionary innovation; visionary leadership; disruptive success; strategy; coorporate strategy; cluster; leadership

\section{INTRODUCTION}

This article describes the results of a case-based qualitative analysis study that was conducted between the second half of 2015 and the first half of 2016. The study intended to measure correlation between the swift success of "Disruptively Successful Startups" (DSS) and two elements: disruptive innovation and visionary leadership. This study is the first leg of a more comprehensive one that will also include an analysis of the organizational changes that need to happen in highly successful startups in order to keep momentum over a long period of time-more than twenty years. The universe of samples for this first study includes cases of three cultural regions or geographical realms [1]: North American, European, and East Asian.

\section{DESCRIPTION OF CONCEPTS OF DISRUPTIVE INNOVATION AND VISIONARY LEADERSHIP}

The concept of disruptive innovation was introduced by Clayton M. in his article "Disruptive Technologies: Catching the Wave" [2]. "A disruptive innovation is an innovation that creates a new market by applying a different set of values, which ultimately and unexpectedly overtakes an existing market-e.g., the lower-priced Ford Model T" [2]. Later, Christensen provided some more details on the nature of disruptive innovation: "Generally, disruptive innovations were technologically straightforward, consisting of off-the-self components put together in a product architecture that was often simpler than prior approaches. They offered less of what customers in established markets wanted and so could rarely be initially employed there. They offered a different package of attributes valued only in emerging markets remote from, and unimportant to, the mainstream" [3]. This is the reason why initially modest startups like Microsoft or Apple can successfully engineer game-changing innovations and so beat incumbents like IBM [4].

Visionary leadership is defined as "the ability to create and articulate a realistic, credible, attractive vision of the future for an organization or organizational unit that grows out of and improves upon the present" [5]. "Visionary leaders are those who inspire extraordinary levels of achievement in followers through an inspiring vision and through other behaviors" [6].

\section{STUDIES ON THE CORRELATION BETWEEN DISRUPTIVE SUCCESS AND DISRUPTIVE INNOVATION AND TRANSFORMATIONAL LEADERSHIP}

Even though there is a large collection of examples that appear to prove the validity of the disruption theory, there are no statistical studies that prove its accuracy-except for the article "Christensen Vs. Lepore: A Matter Of Fact" [7]. This lack of quantitative analysis is mostly due to the qualitative nature of some of the definitions involved in the theory. Also, little work has been done in terms of developing tools for measuring items like disruptiveness-except for the article "Disruptiveness Of Innovations: Measurement And An Assessment Of Reliability And Validity" [8].

In the study "Disruptive Technology or Visionary Leadership?" [9], Gerard Tellis described some limitations on Christensen's theory [3] previously highlighted by researchers like Danneels [10]. Danneels suggested that Christensen did not provide a precise and consistent definition of the term disruptive technology. Tellis specifically considered the issue of sampling. In 1997, Christensen [3] conducted an in-depth analysis of the disk-drive industry for internal validity and provided examples from many other markets for external validity. The key question to be answered in this context is whether these examples were used for inductive purposes - to build the theory-or for deductive purposes - to test the theory. If it is the former, then the logic of sampling is not critical. However, if it is the latter, the researcher should justify how and why the examples were chosen. More generally, a deductive test should include the logic for the sampling of markets and the logic for the sampling of innovations within those markets. The purpose of spelling out the logic of the sampling is to establish that the empirical test is not biased or in favor of the proposed theory. While Tellis [9] found the empirical examples in Christensen [3] persuasive, he could not say the same about the logic of the sampling.

In order to prevent the same criticism, the cases analyzed in this paper were chosen under clear and unbiased criteria.

Tellis also proposed an alternative motive to explain why not only startups but also some incumbents thrive on technological change periods, while others succumb to it [9]. He suggested that the answer lies on visionary leadership. Initially, he backed this thesis on the base of some of his previous research [11], [12]. Then, he conducted a new study that examined the effect of his constructs in a large sample of over 700 firms in seventeen different countries across the globe [9]. This material appeared to prove Tellis' theory. Still, he recognized that there could be other factors that contributed to disruptive success, explicitly naming the Christensen's as one first choice-this invited further research.

The purpose of the study described in this paper was to test the hypothesis that neither the introduction of disruptive innovation nor the existence of visionary leadership alone, but rather the combination of both, is necessary for disruptive 
success. Therefore, both elements usually are not exclusive, but instead jointly necessary-necessary conditions.

\section{SELECTION OF CASES}

In order to choose the cases in the three geographical realms, the following two necessary criteria were applied: (1) the chosen firms were in the global top 100 [13] and (2) in the past, they became world-class industry leaders in a relatively short period of time-less than twenty years-and after leveraging competitive advantages strongly based on disruptive innovation.

The final list of firms chosen for the North American realm was limited to the top five that met these criteria: Apple, Google, Microsoft, General Electric and Facebook-ranks 1, 2, 5, 13, 17 in the global top 100 as per market value (Price Waterhouse Coopers LLP, 2015).

No firm in the European or East Asian realm met criterion 2. If a milder form of discontinuous innovation, revolutionary innovation, is accepted as the type of innovation described in criterion 2, then several European in East Asian firms in the top 100 meet both criteria. In terms of the study, it was taken in consideration that accepting less stringent criteria would help test further the hypothesis of this article. This later objective would be achieved by checking whether those lessened criteria appeared to negatively impact expectable results- lower level of success and/or longer time needed in achieving disruptive success.

Still, the only firm in Europe in the global top 100 that met the new, less stringent criteria was the Spanish firm Inditex, ranked 67 [13].

The three suitable firms in East Asia that ranked higher in the global top 100 were Toyota Motors, Alibaba, and Tencent, ranked 15, 22, and 32 [13].

\section{MEASURING DisRUPTIVE INNOVATION AND VISIONARY LEADERSHIP: QUALITATIVE VERSUS QUANTITATIVE METHODS}

The problem of testing a sample field where particularly unique conditions lead to particularly unique results is that it is unlikely to collect enough samples to conduct a reliable quantitative study. In this context, the only option for testing any hypothesis is qualitative. In the particular scenario of this study, completing a case study appears to be the most logical methodology.

In the future, some new studies could be conducted in order to test whether the studied correlations are gradual and, if so, lesser levels of innovation or visionary leadership still result in increased success rates. In order to test this scenario, a mix of quantitative and qualitative methodologies can then be usede.g., surveys/survey analysis.

\section{METHODOLOGY}

The first factor to be measured is whether high levels of discontinuous innovation-ideally, disruptive innovation-were present in the disruptive success of the studied cases. The second factor to measure is the extent in which the founders or leaders of the studied organizations suit the profile of visionary leadership. In the case of the first factor, the box to be checked is whether a new industry was created - in the case of disruptive innovation, or an existing industry substantially - in the case of revolutionary innovation. In the case of the second factor, the profiles of these leaders were tested against the description provided in the article "Characteristics of Visionary Leadership" [14]. There, visionary leaders are described as (1) creators of a positive and inspirational visions, (2) supporters of organized learning and growth inside the organization, (3) innovators, and
(4) pioneers. Other features that may indicate the value of a given business leader were also taken into consideration. Table 1 below summarizes some of the findings.

TABLE I. FEATURE COMPARISON BETWEEN FIRMS AND FOUNDERS

\begin{tabular}{|c|c|c|c|c|}
\hline $\begin{array}{l}\text { Company } \\
\text { Name }\end{array}$ & $\begin{array}{l}\text { Rank of } \\
\text { most } \\
\text { valuable } \\
\text { firms }\end{array}$ & $\begin{array}{l}\text { Name of } \\
\text { Founder } \\
\text { Leader }\end{array}$ & $\begin{array}{l}\text { Rank } \\
\text { of } \\
\text { richest }\end{array}$ & $\begin{array}{l}\text { Other features on measuring } \\
\text { leadership relevance/impact }\end{array}$ \\
\hline Apple Inc. & 1 & Steve Jobs & Dead & $\begin{array}{l}\text { Ranked in the list of the } 20 \\
\text { most influential Americans of } \\
\text { all times. [15] Several articles } \\
\text { and surveys rank Jobs in the top } \\
2 \text { of the greatest innovators of } \\
\text { all times. [16][17] }\end{array}$ \\
\hline $\begin{array}{l}\text { Google (now } \\
\text { Alphabet, Inc.) }\end{array}$ & 2 & Larry Page & 12 & \\
\hline $\begin{array}{l}\text { Microsoft } \\
\text { Corporation }\end{array}$ & 5 & Bill Gates & 1 & \\
\hline $\begin{array}{l}\text { General } \\
\text { Electric }\end{array}$ & 13 & $\begin{array}{l}\text { Thomas } \\
\text { Edison }\end{array}$ & Dead & $\begin{array}{l}\text { Ranked in the list of the } 20 \\
\text { most influential Americans of } \\
\text { all times. [15] Several articles } \\
\text { and surveys rank Jobs in the top } \\
1 \text { of the greatest innovators of } \\
\text { all times. [16][17] }\end{array}$ \\
\hline Facebook, Inc. & 17 & $\begin{array}{l}\text { Mark } \\
\text { Zuckerberg }\end{array}$ & 6 & $\begin{array}{l}\text { Ranked in the top } 5 \text { of the } \\
\text { greatest innovators of all times } \\
\text { according to the Lemelson- } \\
\text { MIT Invention Index. [17] }\end{array}$ \\
\hline $\begin{array}{l}\text { Toyota Motor } \\
\text { Corporation }\end{array}$ & 15 & $\begin{array}{l}\text { Eiji Toyoda } \\
\text { and Taiichi } \\
\text { Ohno }\end{array}$ & Dead & \\
\hline $\begin{array}{l}\text { Alibaba Group } \\
\text { Holding }\end{array}$ & 22 & Jack Ma & 33 & \\
\hline $\begin{array}{l}\text { Tencent } \\
\text { Holdings }\end{array}$ & 32 & $\begin{array}{l}\text { Ma } \\
\text { Huateng }\end{array}$ & 46 & \\
\hline $\begin{array}{l}\text { Industria de } \\
\text { Diseño Textil, } \\
\text { S.A. (Inditex) }\end{array}$ & 67 & $\begin{array}{l}\text { Amancio } \\
\text { Ortega }\end{array}$ & 2 & \\
\hline
\end{tabular}

Based on the information in this table, it appears that founders either outperform their already outperforming firms, in terms of "value" rankings_-Bill Gates, Mark Zuckerberg, Amancio Ortega, or they enjoy even more prestige and recognition than their firms - Steve Jobs and Thomas Edison. Only in the case of Larry Page does the profile of the leader appear to be less remarkable than that of his company.

The cases in Asia need further analysis. This will be explained later in this paper.

\section{ANALysis of Five CASES IN NORTh AMERICA}

\section{A. Apple Inc. - The USA}

\section{1) Leadership: Steve Jobs}

Walter Isaacson, Jobs' official biographer, described him as a "creative entrepreneur whose passion for perfection and ferocious drive revolutionized six industries: personal computers, animated movies, music, phones, tablet computing, and digital publishing. " [18]

Elements of disruptive innovation can be found in at least four of the items in the list: personal computers, music (distribution), tablet computing, and digital publishing. The other two should be linked to revolutionary innovation.

Based on the previous review of other bibliography, Jobs clearly scores high in descriptions (3) innovator and (4) pioneer.

Creator of a positive and inspirational vision:

In the documentary film "Triumph of Nerds" [4], Jobs said: 
"So I saw a lot of this and to me the spark of that was that there was something beyond sort of what you see every day. It's the same thing that causes people to want to be poets instead of bankers. And I think that's a wonderful thing. And I think that that same spirit can be put into products, and those products can be manufactured and given to people and they can sense that spirit."

In the same documentary, one of the members of the original team that developed the Apple II stated these words about the team that Jobs put together:

"I love these people (in front of the pictures of six of the team members, including Steve Jobs). They are like family to me, really. And we were united by this common bond, to try to do this incredible thing with the Mac."

Supporter of organized learning and growth inside the organization:

"That's how I see business: Great things in business are never done by one person. They're done by a team of people." [19]

"The people who are doing the work are the moving force behind the Macintosh. My job is to create a space for them, to clear out the rest of the organization and keep it at bay. " [20]

"Innovation has nothing to do with how many R\&D dollars you have. When Apple came up with the Mac, IBM was spending at least 100 times more on $R \& D$. It's not about money. It's about the people you have, how you're led, and how much you get it." [21]

\section{2) Disruptive Innovation: personal computers}

Despite the fact that Jobs managed to be involved in the early success of products related to four different disruptive innovations and founded several highly successful companies, he said:

"I feel incredibly lucky to be at exactly the right place, in Silicon Valley, and at exactly the right time, historically, where this invention (personal computers) has taken form." [4]

In other words, Jobs believed that his first "disruptive success" would have never occurred without the context of a unique disruptive innovation happening in one single spot of the planet at a given time.

\section{B. Google/Alphabet Inc. and General Electric - The USA}

Even though the company was started by two students at Stanford, the beginnings apparently were not as humble as those of other earlier startups in Silicon Valley. The two founders already raised an initial capital of 1 million USD by the time they established the company in 1998 [22].

Google's initial success was not based on disruptive, but rather on revolutionary innovation-that was relevancy ranking in the search engine sector [23][22].

Over the last eighteen years, Google has managed to consistently develop products in various sectors that incorporate evolutionary or revolutionary innovation-e.g., Gmail, Chrome [22]. Google also mastered a different strategy for leading innovation and entering new markets: acquisitions-e.g. Android, Google Earth, Google Maps, YouTube [24], [25].

There are uneven opinions regarding the quality of the leadership that Page brought to the organization, especially in the early years [26]. Some trends in Page's personality, for example his tendency towards introversion, may color his leadership style, but there is little doubt of the leadership capabilities of Page in roles like (1) creator of positive and inspirational visions, (2) supporter of organized learning and growth inside the organization, and (3) innovator [27][28].

Google's business model has been labelled as continuous disruptive innovation [29] or continuous innovation [23], which are different definitions and concepts than Christensen's. Google's innovation development model, based on a corporate culture built around a hub of talent-Googleplex - creativity, and team work, is similar to the model that Edison set up for General Electric in the first industrial research park ever, Menlo Park [23], [30][31].

Google, and General Electric--which was founded in 1889 by Thomas Edison [32]-adopted from the early beginning a strategy for developing innovation that was less based on sparks of disruptive innovation and genius and more on systematic approach and team work [33]. This would be, in fact, an alternative model to the "disruptive innovation + visionary leadership" recipe for success that this study tries to validate. The former model should usually produce peaks of innovation and growth lower in high-implying less impact-but more frequent in time [31] [29]. The former is not based on the extraordinary and, therefore, it should be more sustainable over time. However, in terms of acting as an effective catalyzer for disruptive success, the proportion between innovation-related startups in the studied cases that succeeded based on this article's hypothesis versus Google's or GE's approach is two to one, at least for the global top 20 [13].

Nevertheless, the resulting ratio is two-to-one because General Electric counts against both options.

Thomas Edison ranks in the top of almost every list of greatest innovators and entrepreneurs of all times. He registered more than 1000 patents in the US alone [31] and founded more than 300 companies [31][15] [16][17].

His Menlo Park laboratory and, later, his larger West Orange, New Jersey laboratory, developed a long list of unique disruptive innovations over the 35 years that Edison worked there [31]. Some of the most relevant inventions of these laboratories were the phonograph, the first system of incandescent electric light and power, the first motion picture camera, and the alkaline storage battery [31].

What makes the case of General Electric particularly interesting is that it constitutes a unique example of disruptive success due to the combination of a model based on unique leadership and disruptive innovation, and a model based on team-work and systematic approaches towards innovation, which can be compared to "young" Apple's versus Google's. Maybe, that combination came as just a natural result from the mind of Edison due to extraordinary circumstances in a particular moment in human history when disruptive innovations were not such a rare occurrence and could be found in a systematic way. Google may be so successful now because it found a similar niche.

The fact that General Electric was designed to undertake a systematic, team-work approach to innovation probably made the firm less dependent on unique leadership or disruptive innovation. General Electric is the only American company that has been in the top for more than 100 years. It was in the original Dow Jones Industrial Average (DJIA), which was created in 1896, and never left it after 1907 ("History of the Dow-Timeline of Companies" 2003). General Electric has consistently been in the top 10 of Fortune 500 since 1955 [35]. 


\section{Microsoft and Facebook - The USA}

Bill Gates - founder of Microsoft-is the richest man on earth, and Zuckerberg - founder of Facebook - is number five [36]. Bill Gates and Zuckerberg apparently are as introversive as Larry Page, [25] [4] but not as charismatic as Steve Jobs [37][4][38], [39]. Nevertheless, there is no doubt that Gates and Zuckerberg are both extraordinary visionary leaders [4] [38], [39][40][41].

Also, the earliest entrepreneurial project that each of them thrived on was a disruptive innovation - personal computers and social networks. Therefore, the hypothesis of this article appears to be true for these two cases.

However, it can be noted that, over the last decade, both companies - and maybe Apple, too-evolved towards Google's and General Electric's model. Microsoft, Apple, and Facebook did not produce any disruptive innovation in the last five years, and focused on revolutionary or evolutionary ones-e.g., iPhone I, II, III, IV, V, and VI; Windows 10. They also adapted a strategy of frequent acquisitions, apparently in search of the innovation edge they may not be able to produce by themselves anymore. Facebook acquired Instagram for 1 billion USD (2012), Face.com for 100 million USD (2012), Atlas Advertiser Suite for 100 million USD (2013), WhatsApp for 19 billion USD (2014), Oculus VR for 2 billion USD (2014), Ascenta for 2 billion USD, (2014) as well as many smaller ones [42]. In the last two decades, Microsoft has made eight acquisitions worth over 1 billion USD: Skype (2011), aQuantive (2007), Fast Search \& Transfer (2008), Navision (2002), Visio Corporation (2000), Yammer (2012), Nokia (2013), and Mojang (2014). Microsoft has also purchased several stakes of relevant companies - e.g., Comcast — valued at more than a billion USD. It obtained an $11.5 \%$ stake in Comcast for 1 billion USD, a $22.98 \%$ stake in Telewest Communications for 2.263 billion USD, and a $3 \%$ stake in AT\&T Inc. for 5 billion USD. It also diversified towards other industries like gaming (Xbox) and mobile (Windows Mobile OS). [43]

Lesson learned: diversification and partnerships, like acquisitions, appear to be a strategic option for those depending less on visionary leadership and generation of disruptive innovation.

The fact that the only five innovation-related firms in the global top 20 are in the North American realm implies that there is either a context or a cultural factor to it, or maybe both. However, the fact that four of these companies can be tracked to a much smaller geographical area, Silicon Valley, suggests a mostly contextual phenomenon, or third element, that may be necessary for some forms of disruptive innovation: clusterization [44]. Instead, the leaders of these firms appear to have in common a different feature: except for Jobs, they all were graduate or $\mathrm{PhD}$ students at two of the most elite American universities - Harvard and Stanford. This feature may imply that disruption innovation and visionary leadership tend to flourish in specific but different environments, while only the (rare) intersection of both result in DSS.

\section{ANALYSIS OF ONE CASE IN EUROPE}

\section{$A$. Industria de Diseño Textil (Inditex) - Spain}

Inditex group, a textile fashion retailer firm owner of brands like Zara, ranks 67 in the global top 100 [13]. Amancio Ortega, its founder, is the second richest man in the world [36].

The success of Inditex - and H\&M, its main competitor-is based on a revolutionary innovation called fast fashion [45]. Inditex devised a model of supply chain, Agile Supply Chain
(ASC), that allows the firm to update fashion products "just in time" [46][45]. In this process, store managers communicate customer feedback on what shoppers like, what they dislike, and what they are looking to buy [46][45]. That data is instantly funneled back to Zara's designers, who begin sketching on the spot [46][45]. Inditex's Supply Chain Operations (SCO) focus on three aspects: maximizing resources used, minimizing inventory, and minimizing lead times [46]. Inditex keeps a significant amount of its production in-house and makes sure that its own factories reserve $85 \%$ of their capacity for in-season adjustments [45]. In-house production allows the organization to be flexible in the amount, frequency, and variety of new products to be launched [45].

This model of production, based on flexibility and speed, requires a vertically integrated value chain, which is very different, for instance, of the franchise model of Benetton and Mango, or that of other retail shops that purchase from a variety of manufacturers.

"Reclusive", "secretive," and "reserved" are words frequently used to describe Amancio Ortega [47]. Ortega has guarded his privacy so closely that his company only first released a photograph of him when the firm was listed in 2001 [47]. Ortega eats lunch with his employees in the company cafeteria. He can regularly be found sharing a table on the factory floor with some of the designers, fabric experts, and buyers [48].

"Dear colleague, dear friend". These are exactly the same words that both Steve Jobs and Amancio Ortega used once in letters addressed to employees [49].

\section{AnAlysis of Three CASES IN EAST Asia}

\section{A. Toyota Motor Corporation - Japan}

\section{1) Lean Manufacturing}

Towards the end of the Second World War, Taiichi Ohno worked as a production engineer for Toyota, a Japanese car manufacture [50]. In those days, Toyota's productivity was quite below that of Detroit's mighty competitors, the Big Three: General Motors, Ford, and Chrysler [50]. At that time, Toyota's President declared: "We must catch up with America within three years" [50].

It was an American supermarket, Piggly Wiggly, that initially inspired Ohno [51][52]. He observed how customers regularly picked up a number of items from shelves and, in turn, the supermarket quickly and precisely replenished them [51]. The model gave Ohno ideas on how to reduce inventory and simplify assembly lines [53], [54][51]. Based on those ideas, Ohno and his managers devised the Toyota Production System, more broadly known as lean manufacturing. That gave Toyota a big edge in productivity and quality control [53], [54]. The new system ensured Toyota's position as the industry leader. Its principles were also adopted across sectors and countries.

Apparently, Ohno applied a revolutionary innovation in supply chain management in a similar fashion to the way Amancio Ortega did in clothing manufacturing.

\section{2) Leadership}

\section{Taiichi Ohno once said:}

"The Toyota style is not to create results by working hard. It is a system that says there is no limit to people's creativity. People don't go to Toyota to work, they go there to think" [55]. 
"When you go out into the workplace, you should be looking for things that you can do for your people there. You've got no business in the workplace if you're just there to be there. You've got to be looking for changes you can make for the benefit of the people who are working there" [56].

"A leader in continuous improvement activities must be deemed dependable and trustworthy by his workers. He must proactively initiate continuous improvement as he sees it in order to make workers' operations easier. This will win their respect and generate an expectation toward future improvements" [57]

\section{3) Remarks}

Unlike the previous cases, Toyota was neither a startup nor was Ohno its founder. Ultimately, though, the combination of Onho's leadership and innovations transformed Toyota from being an average car supplier to becoming the global leader. That can still be described as disruptive success.

B. Alibaba Group Holding Limited and Tencent Holdings Limited - China

\section{1) Jack Ma, founder of the Alibaba Group}

"On a trip to the United States on behalf of the Hangzhou city government in 1995, Ma had his first encounter with the Internet and saw the lack of Chinese Web sites as a great business opportunity. (...) Ma persuaded his team at the ministry to go back to Hangzhou with him and found the Alibaba Group. Ma was convinced that the small-business-to-small-business Internet market had much greater potential for growth than the business-to-consumer Internet market had. Growth was rapid; in 2005 Alibaba attracted the attention of the American Internet portal Yahoo!, which bought a 40 percent stake, and in 2007 Alibaba.com raised $\$ 1.7$ billion dollars in its initial public offering (IPO) in Hong Kong. " [58]

\section{2) Ma Huateng founder of Tencent Holdings Ltd.}

"Ma Huateng studied computer science at Shenzhen University, where he earned (1993) a Bachelor of Science degree. He then worked in research and development for China Motion Telecom Development Ltd. before founding (1998) Tencent with several friends. A year later the company launched the Internet-based QQ service (then called OICQ), which soon became one of China's most-popular instantmessaging platforms. Tencent subsequently gained the backing of two overseas venture-capital firms, and in June 2004 the firm raised nearly $\$ 200$ million when it went public on the Hong Kong stock exchange.

Under Ma's leadership, Tencent greatly expanded its offerings to provide users with a range of what the company described as "online lifestyle services." By late 2015 QQ had approximately 850 million monthly active users, and WeChata mobile instant-messaging app that was first introduced in 2011-had some 650 million users. Tecent also operated the social networking site Qzone, which boasted more than 670 million monthly active users in 2015, making it the world's third largest social network, behind only Facebook and YouTube. Tencent's immense success made Ma, who was widely referred to as "Pony" Ma (the nickname was a play on his surname, which means "horse" in Chinese), one of the wealthiest individuals in China." [59]

\section{Chinese IT cluster or "Silicon Valley"?}

"Mr. Chen is part of a growing number of entrepreneurs who got their start at China's three leading Internet firms-
Alibaba, Tencent Holdings Ltd., and Baidu Inc.- and are now trying their luck at their own ventures. Taking advantage of the extensive alumni network to recruit talent and raise capital, the movement is reminiscent of the wave of Silicon Valley startups that were created by veterans of U.S. tech giants such as PayPal Inc. and Google Inc. in the past decade. The upshot is a vibrant tech scene in China, with billion-dollar startup valuations previously seen only in the U.S. " [60]

\section{1) Remarks}

The profile of leadership that both Jack Ma and Ma Huateng lead with clearly contains the element "visionary"-e.g., (4) pioneer, (3) innovators. Probably, innovations linked to them could only be considered revolutionary or evolutionary. However, the fact that they applied these innovations in a large but still unspoiled market - China-made them behave as disruptive innovations.

Both, Alibaba and Tencent were modest startups that became bigger than any Chinese large company (beside the ones in the top 5) in less than twenty years [13] [58] [59].

\section{GENERAL REMARKS, CONCLUSIONS AND PROPOSAL OF SUGGESTED RESEARCH}

\section{$A$. General Remarks}

- Studied cases of European and Eastern Asian firms involved in lesser levels of discontinuous innovation than those in North America.

- Levels of visionary leadership could be considered more or less even in the three realms - except, maybe, for Edison and Jobs.

- Cases of disruptive success were less impressive in Europe and Eastern Asia than in North America, for the last few decades.

\section{B. Conclusions}

The sample is not large and general enough to predict that only the highest level of discontinuous innovation (disruptive) can produce disruptive success. In fact, Google would contradict this hypothesis. However, some other fair conclusions could be extracted:

- Most likely, visionary leadership is a necessary condition for disruptive success.

- A combination of disruptive, revolutionary, and evolutionary innovation is a necessary condition for disruptive success.

- The more abrupt and/or lengthy the cycle of peaks of innovation, the more chances are that disruptive success happens.

- At disruptive success levels, there is a linear correlation - not a binary one-between these same levels and the levels of discontinuous innovation and visionary leadership.

Therefore, it can be concluded that there is a strong correlation between the highest disruptive successes of innovation companies created in the last century and in the top nowadays, and two elements: discontinuous (ideally, disruptive) innovation and visionary leadership. Both are necessary conditions. Christensen's hypotheses on disruptive innovation and those of many on visionary leadership are not competing or mutually exclusive, in terms of facilitating disruptive success, but, on the contrary, complementary. 
- Clues in the cases-e.g., Apple, Google, Microsoft, Facebook, Alibaba, Tencent-strongly suggest that a third element, a special location in time and space, may also be a necessary condition. More research would be needed on this.

- An alternative formula, based on team-based and systematic innovation, may also produce disruptive success - e.g., Google, General Electric, Toyota. But this approach does not work so well for incumbents [4]. More research is needed in order to determine how feasible this complex approach is in the context of humble startups.

- However, this alterative formula appears to be a good strategy for long-term growth and sustainability once disruptive success is achieved. More research is needed on this topic.

- Alternative strategies that would help compensate a decreased internal capacity for creating revolutionary or disruptive innovation are active policies of acquisitions and diversifications - partnerships. More research is needed on this topic.

- More research is needed in order to clearly outline the exact profile of leadership that better correlates to disruptive success. Different trends described by models like those of visionary leadership, the one used in this paper, transformational leadership, [61] or charismatic leadership [62] should be tested.

\section{REFERENCES}

[1] H. J. De Blij, P. O. Muller, and J. Nijman, Geography: realms, regions, and concepts. Hoboken, NJ: Wiley Global Education, 2013.

[2] C. M. Christensen and J. L. Bower, "Disruptive Technologies: Catching the Wave.," Harv. Bus. Rev., pp. 43-53, 1995.

[3] C. M. Christensen, The Innovator's Dilemma: When New Technologies Cause Great Firms to Fail. Harvard Business Press, 1997.

[4] P. Sen, Triumph of the Nerds. 1996.

[5] S. P. Robbins, Organizational Behavior. Upper Saddle River, NJ: Prentice Hall, 2003.

[6] I. SAGE Publications, S. Carey, and S. A. Kirkpatrick, "Visionary Leadership Theory. Encyclopedia of Leadership. SAGE Publications, Inc." pp. 1616-1620, 2004.

[7] T. Thurston, "Christensen Vs. Lepore: A Matter Of Fact," $\begin{array}{llll}\text { TechCruch.com, } & 2014 . & \text { [Online]. }\end{array}$ http://techcrunch.com/2014/06/30/christensen-vs-lepore-a-matter-offact/. [Accessed: 23-May-2015].

[8] V. Govindarajan and P. K. Kopalle, "Disruptiveness of innovations: measurement and an assessment of reliability and validity," Strateg. Manag. J., vol. 27, no. 2, pp. 189-199, 2006.

[9] G. J. Tellis, "Disruptive Technology or Visionary Leadership?," J. Prod. Innov. Manag., vol. 23, no. 1, pp. 34-38, 2006.

[10] E. Danneels, "Disruptive technology reconsidered: A critique and research agenda," J. Prod. Innov. Manag., vol. 21, no. 4, pp. 246-258, 2004.

[11] R. K. Chandy, G. J. Tellis, D. J. MacInnis, and P. Thaivanich, "What to say when: Advertising appeals in evolving markets," J. Mark. Res., vol. 38 , no. 4, pp. 399-414, 2001.

[12] G. J. Tellis and P. N. Golder, "First to market, first to fail? Real causes of enduring market leadership," MIT Sloan Manag. Rev., vol. 37, no. 2, pp. 65-75, 1996.

[13] PriceWaterhouseCoopers LLP, "Global Top 100 Companies by market capitalisation," 2015.

[14] M. Patrick, "Characteristics of Visionary Leadership," Chron.com. [Online]. Available: http://smallbusiness.chron.com/characteristicsvisionary-leadership-31332.html. [Accessed: 30-May-2015].

[15] Time, "The 20 Most Influential Americans of All Time," Time, 2012. .

[16] R. Allis, "The twelve greatest innovators of all times," The startup guide, 2014. [Online]. Available: http://startupguide.com/world/greatestinnovators/. [Accessed: 18-May-2016].
[17] MIT, "Young Americans Recognize the Impact of Innovation on U.S. Economy," Lemelson-MIT Program, 2012. [Online]. Available: $\mathrm{http}: / /$ lemelson.mit.edu/news/young-americans-recognize-impactinnovation-us-economy. [Accessed: 18-May-2016].

[18] W. Isaacson, Steve Jobs. New York: Simon and Schuster, 2015.

[19] B. Griggs, "10 great quotes from Steve Jobs," CNN, 2012. [Online]. Available: http://edition.cnn.com/2012/10/04/tech/innovation/steve-jobsquotes/. [Accessed: 18-May-2016].

[20] L. Kahney, Inside Steve's Brain: Business Lessons from Steve Jobs, the Man Who Saved Apple. London: Atlantic Books, 2009.

[21] D. Kirkpatrick, "The Second Coming of Apple Through a magical fusion of man--Steve Jobs--and company, Apple is becoming itself again: the little anticompany that could.," Fortune Mag., 1998.

[22] W. L. Hosch, "Google Inc.," Encyclopædia Britannica Inc., 2015. [Online]. Available: http://www.britannica.com/topic/Google-Inc. [Accessed: 18-May-2016].

[23] A. Steiber, The Google Model: Managing Continuous Innovation in a Rapidly Changing World (Management for Professionals). Springer, 2014.

[24] S. Adams, "Leadership Tip: Hire the Quiet Neurotic, Not the Impressive Extrovert," Forbes.com, 2013. [Online]. Available: http://www.forbes.com/sites/susanadams/2013/04/11/leadership-tip-hirethe-quiet-neurotic-not-the-impressive-extrovert/\#7093139e24ea. [Accessed: 18-May-2016].

[25] R. Fujioka, "How Bill Gates, Larry Page, and Mark Zuckerberg All Thrive as Introverts," Inc., 2016. [Online]. Available: http://www.inc.com/russfujioka/how-bill-gates-larry-page-and-mark-zuckerberg-all-thrive-asintroverts.html. [Accessed: 18-May-2016].

[26] N. Carlson, "The Untold Story Of Larry Page's Incredible Comeback," Business Insider, 2014. [Online]. Available: http://www.businessinsider.com/larry-page-the-untold-story-2014-4. [Accessed: 18-May-2016].

[27] S. Akinyemi, "Leadership Style," 2014.

[28] V. Elmer, "What would Larry Page do? Leadership lessons from Google's doyen," Fortune Magazine, 2011. [Online]. Available: http://fortune.com/2011/04/18/what-would-larry-page-do-leadershiplessons-from-googles-doyen/. [Accessed: 18-May-2016].

[29] C. Catapano, "What is Continuous Disruptive Innovation?," Bridgesphere, 2010. [Online]. Available: http://bridgesphere.com/whatis-continuous-disruptive-innovation/. [Accessed: 18-May-2016].

[30] L. Sun, "Google and Innovation - A History," businessdictionary.com, $2016 . \quad$ [Online]. Available: http://www.businessdictionary.com/article/710/google-and-innovation-ahistory/. [Accessed: 18-May-2016].

[31] Rutgers, "Edison's Patents," The Thomas A. Edison Papers Project, 2012. [Online]. Available: http://edison.rutgers.edu/index.htm. [Accessed: 18May-2016].

[32] Encyclopædia Britannica, "General Electric Co. (GE)," Encyclopædia Britannica, $2014 . \quad$ [Online]. Available: http://www.britannica.com/topic/General-Electric-Co. [Accessed: 19May-2016].

[33] Q. Hardy, “Google's Innovation -And Everyone's?,” Forbes.com, 2011. [Online]. http://www.forbes.com/sites/quentinhardy/2011/07/16/googlesinnovation-and-everyones/\#60a52aa8331a. [Accessed: 18-May-2016].

[34] "History of the Dow - Timeline of Companies," Quasimodos, 2003. [Online]. Available: http://www.quasimodos.com/info/dowhistory.html. [Accessed: 08-Feb-2015].

[35] Various, "Fortune 500 Companies - Archived List of Best Companies from 1995," Fortune Magazine, 2014. [Online]. Available: http://archive.fortune.com/magazines/fortune/fortune500_archive/full/19 55/. [Accessed: 08-Feb-2015].

[36] Forbes, "The World's Billionaires List - Forbes," Forbes Media LLC, 2016. [Online]. Available: http://www.forbes.com/billionaires/list/. [Accessed: 13-May-2016].

[37] S. Levy, "Steve Jobs," Encyclopædia Britannica Inc., 2015. [Online]. Available: http://www.britannica.com/biography/Steve-Jobs.

[38] Computer History Museum, "Mark Zuckerberg \& Facebook - Inside Story of the World's Fastest-growing Company 2014," Computer History Museum, 2014. [Online]. Available: https://www.youtube.com/watch?v=Il507j6qojg. [Accessed: 21-May2016].

[39] C. Rose, "Charlie Rose - Interview With Senior Facebook Leadership Mark Zuckerberg, CEO, Sheryl Sandberg, COO,” CBS, 2014. [Online]. Available: https://www.youtube.com/watch?v=I1507j6qojg. [Accessed: 
21-May-2016].

[40] Encyclopædia Britannica, "Bill Gates," Encyclopædia Britannica Inc., 2016.

[41] Encyclopædia Britannica, "Mark Zuckerberg," Encyclopædia Britannica, 2016. [Online]. Available: http://www.britannica.com/biography/MarkZuckerberg. [Accessed: 18-May-2016].

[42] A. Hayes, "Facebook's Most Important Acquisitions," Investopedia.com, 2016. [Online]. Available: http:/www.investopedia.com/articles/investing/021115/facebooks-mostimportant-acquisitions.asp. [Accessed: 20-May-2016].

[43] Encyclopædia Britannica, "Microsoft Corporation," Encyclopædia Britannica, 2016. [Online]. Available: http://www.britannica.com/topic/Microsoft-Corporation. [Accessed: 18May-2016].

[44] M. Porter, Competitive Advantage: Creating and Sustaining Superior Performance. New York: The Free Press, 1985.

[45] C. Lu, "Zara's secret to retail success - its supply chain," tradegecko, 2014. [Online]. Available: https://www.tradegecko.com/blog/zarasupply-chain-its-secret-to-retail-success. [Accessed: 20-May-2016].

[46] G. Zhelyazkov, "Agile Supply Chain: Zara's case study analysis." Strathclyde University of Glasgow, Glasgow, 2010.

[47] Reuters and smh.com.au, "The reclusive billionaire: secret life of Zara boss Amancio Ortega and his 'fast fashion' empire," smh.com.au and Reuters, 2013. [Online]. Available: http://www.executivestyle.com.au/the-reclusive-billionaire-secret-lifeof-zara-boss-amancio-ortega-and-his-fast-fashion-empire-2fhne. [Accessed: 20-May-2016].

[48] B. Marlow, "The humble life of Zara owner Amancio Ortega is to be admired," The Telegraph, 2015. [Online]. Available: http://www.telegraph.co.uk/finance/newsbysector/retailandconsumer/11 656753/The-humble-life-of-Zara-owner-Amancio-Ortega-is-to-beadmired.html. [Accessed: 20-May-2016].

[49] O. Novoa Ojea, "Madera de líder," El Mundo, Madrid, 23-Jan-2011.
[50] Kaizen Institute, “Taiichi Ohno's contribution,” Kaizen Institute, 2013. [Online]. Available: https://kaizeninstituteindia.wordpress.com/2013/10/17/taiichi-ohnoscontribution/. [Accessed: 21-May-2016].

[51] Toyota, “Taiichi Ohno," Toyota, 2004. [Online]. Available: http://www.toyota-

global.com/company/toyota traditions/quality/mar_apr 2004.html. [Accessed: 21-May-2016].

[52] M. Bruce, "Piggly Wiggly: An Inspiration for the Toyota Way," zraydelta, 2011. .

[53] M. Schuman, "Toyota Production System (1988), by Taiichi Ohno," Time, 2011. [Online]. Available: http://content.time.com/time/specials/packages/article/0,28804,2086680 _2086683_2087688,00.html. [Accessed: 21-May-2016].

[54] T. Ohno, Toyota Production System: Beyond Large-Scale Production. London: Productivity Press, 1988.

[55] Ash Maurya, Running Lean. Sebastopol, CA: O’Reilly, 2012.

[56] K. Shimokawa and T. Fujimoto, The Birth of Lean. Cambridge, MA: Lean Enterprise Institute, 2009.

[57] Shmula, "Taiichi Ohno Quotes on Lean Leadership," Shmula, 2011. [Online]. Available: http://www.shmula.com/taiichi-ohno-on-leanleadership/9274/. [Accessed: 22-May-2016].

[58] E. Gregersen, "Jack Ma," Encyclopædia Britannica, 2016. .

[59] S. Hollar, "Ma Huateng," Encyclopædia Britannica, 2016.

[60] Juro Osawa, "Behind China's Billion-Dollar Startups: Alumni of Alibaba, Tencent," The Wall Street Journal, 2014. [Online]. Available: http://www.wsj.com/articles/alibaba-tencent-alumni-fuel-chinas-startupsuccess-1429028237. [Accessed: 22-May-2016].

[61] J. M. Burns, "leadership. NY.” Harper \& Row, 1978.

[62] M. Weber, Economy and Society. Univ of California Press, 1922. 